\title{
Em busca da contemporaneidade perdida
}

Com a publicação de ESTUDOS AVANÇADOS, trazemos ao leitor a variada e fecunda produção que vem sendo trabalhada, avaliada e decantada no mais jovem instituto da USP, o Instituto de Estudos Avançados (IEA-USP).

Assim, após seu primeiro ano de inquieta exıstência, já tendo experimentado um número significativo de hipóteses de trabalho e oferecıdo ao corpo acadêmico - e não só a ele! - vanados estímulos que sugerem novas formas de partıcıpação e de convivência intelectual, o IEA lança ao debate alguns estudos e ensaios inovadores.

Desafio imenso, numa universidade burocratizada que se viu obrigada a acolher e aperfeiçoar durante décadas a dıvisão ideológıca do trabalho intelectual. Divisão ideológica que, de resto, marca a vida universitána brasıleıra contemporânea, regendo todos os atos, simbolos e produtos de nosso mundo universitário. Nessa perspectiva, ESTUDOS AVANÇADOS abrigará preferencialmente escritos que estımulem as análıses e as reflexôes de caráter interdisciplinar. $\mathrm{Ou}$, se se preferır, produções vıncadas pela medıtação transdisciplinar.

ESTUDOS AVANÇADOS pretende ser uma alavanca a mals no esforço necessariamente coletivo - de reerguimento da USP. Crıar uma respiração na Unıversidade, lembrá-la de seus compromissos intelectuais mais altos e a responsabilidade politica de seu corpo acadêmico, composto por intelectuas que devem formar novos quadros e produzır ciência e cultura para nossa sociedade.

A nova publıcação não pretende, também no campo editorıal, desempenhar ou substituir os papéis dos institutos, faculdades e museus existentes em nossa universidade. Mas envidará seus melhores esforços no sentıdo de criar espaços para a reflexão onginal, estimulando linhas de investıgação sobre determinados temas e problemas que vêm sendo dispersamente discutidos pela comunidade. Temas e problemas já agora adotados e priorizados pelo IEA, e que vão se aglutinando $\mathrm{cm}$ áreas do conhecimento tais como:

Biologia Molecular, Ciências Ambientais, Economia e Polítıca, Históna das Mentalidades, Música (Eletrônica, princıpalmente).

Cabe advertır: tais áreas do conhecimento constıtuem ênfases inıciass na política geral do Instituto, que não excluem outras iniciativas conjunturars. A densidade intelectual alcançada nesses campos indicados - ou a massa critica exıstente, na expressão cara aos físicos. . . - e a abrangência dos enfoques adotados já permitem tornar nossas as palavras de Machado de Assis: " $a$ dispersão näo lhes tira a unidade, nem a inquietude a constância".

Grupos de Estudos de média ou curta duração que já operam no IEA também não excluem, por certo, a discussão de suas problemáticas com os Colegas porventura interessados. Mencione-se, como exemplo mais visível, a existência e a intervenção de equipe interdisciplinar voltada para o tema da Educação e a Escola Pública, nestes tempos de Congresso Constituinte. Cumpre-se aqui uma das funções do IEA, no sentido de estimular a discussão de temas magnos do País, no interior da USP. 
Fermentar, eıs uma palavra-chave já incorporada no cotıdıano dos frequentadores do IEA, e que ajuda a definır o papel da nova Unıdade. Vai-se desenhando, dessa forma, o perfil do modelo uspiano de um instituto dessa natureza.

Já contando com a presença de professores-vısıtantes em suas atıvidades iniciats, como o junsta Raymundo Faoro e o historiador Manuel Moreno Fraginals (ambos em 1986), e o compositor e professor H.J. Koellreutter, o crítico e escritor Silviano Santiago, o físico nuclear Bernard Feld, o cientista polítıco Agustín Cueva, o tradutor e ensaísta José Paulo Paes, o historıador das ıdéıas e da urbanızação Richard Morse, o historiador da cultura e da polí ica contemporâneas Marc Ferro (todos em 1987), o IEA tem assıstıdo à amplıação de um sıgnıficatıvo espaço intelectual. Espaço exercitado por um número considerável de pesquisadores, escritores e artıstas nacronais e internacionaıs, que buscam aquı a interdiscıplınarıdade perdida - e suas produções procuraremos estampar em ESTUDOS AVANÇADOS Nessa medıda, além dos trabalhos produzıdos no interıor do IEA (como os de Faoro, Morse, Jean Louis Koszul, Feld etc.), tex tos de seminários e conferências como os do historiador das mentalıdades Michel Vovelle (Sorbonne) ou do eccnomista John Kenneth Galbraith, entre outros, serão divulgados, ao lado de semınános de reflexão sobre questões universıtárıas ou sobre problemas contemporâneos (Energı, Descolonızação, Ecologia etc.).

Como pensar a nossa contemporaneldade em suas varıdas dımensōes e ımpasses, eıs um dos objetıvos de ESTUDOS AVANÇADOS.

"Avançados em quêे?", perguntava o cientısta social e professor emérıto da USP, Florestan Fernandes, em setembro de 1986, ao entrar pela primeıra vez em sua carreıra no salão nobre de um renovado Conselho Unıversıtárıo para proferır a Conferência do Mês do IEA. Respostas a essa pergunta desafiadora deverão estar sendo procuradas a cada passo do IEA. Mas lıgadas a outra questão, já agora por nós formulada afinal, uma unıversıdade como a USP, não deverı ser, toda ela, avançada? De fato, em inúmeros setores, ela vem cumprindo seu papel e se atualızando, respondendo aos problemas que a difícll contemporaneidade brasıleıra propõe. Mas em outros não, sobretudo por terem perdıdo tars setores o ideal de universitas, necessariamente interdisciplinar, ou por terem se conformado com as regras do estamento burocrátıco uspiano. Nas palavras de Antônıo Cândido, o IEA relança a bandeira do "heterodoxo na história da Universidade de São Paulo", de ser uma "ala móvel, podendo significar muito no cultivo do espirito critico e renovador que nutre as visôes heterodoxas, como as nutru em 1934".

Em qualquer hipótese, o desafio é grande 'qual o compromısso da Unıversıdade e de seus intelectuass na construção da nova sociedade civil e na definıção de padrōes civilızatórıs compativeıs com a dıgnıdade humana neste fim de milên10?

ESTUDOS AVANÇADOS propõe desde logo a seus leıtores a medıtação ınıcıal, necessarıamente coletıva: a Universıdade tem estımulado a socıedade a avançar em quass direções? 